Julita PASZKO, MSc

Faculty of Economics and Finance, University of Bialystok

e-mail: j.paszko@uwb.edu.pl

ORCID: 0000-0002-6794-6939

DOI: $10.15290 /$ oes.2020.03.101.09

\title{
INTELLECTUAL CAPITAL OF EUROPEAN UNION COUNTRIES (EU-28) - MEASUREMENT CONCEPT ${ }^{1}$
}

\begin{abstract}
Summary
Purpose - The aim of the present research paper is to enrich the achievements of science through a description of a theoretical-methodological approach to measuring the national intellectual capital (NIC) along with its application in the evaluation of the European Union countries (2015).

Research method - The synthetic indicator, describing the intellectual capital of the EU countries was quantified by using the TOPSIS method. The year 2015 is the study period.

Results - The estimation results confirm the diversity of the intellectual capital level in the 28 countries of the EU. The highest index value applies to Sweden. Romania takes the last - 28th place and belongs to the fourth typological group with a very low potential of intellectual capital.

Originality / value / implications / recommendations - The new perspective on defining and taxonomy of intellectual capital (including ecological capital) is a kind of novum in this area. As a result, the elaborated ranking of the EU countries provides a new, wider perspective on the intellectual capital issues.
\end{abstract}

Keywords: national intellectual capital (NIC), human capital, social capital, structural capital, ecological capital, TOPSIS

JEL Classification: C38, O15, O34, O52

\section{Introduction}

The concept of intellectual capital has become popular due to the expansion of the list of economic growth factors so as to include intangible capitals, which occurred in the 80's and 90's of the previous century [Ståhle et al., 2015, p. 20; Paszko, 2019, p. 144]. Initially, a reporting gap, a difference between the market value of a company and its accounting value, was discovered [Pedru et al, 2018, p. 411] and defined as intellectual capital. The microeconomic scale of research was extended in 1999 to include the national perspective (national intellectual capital - NIC) due to the first attempt to measure the intellectual capital of Sweden [Michalczuk, Fiedorczuk, 2017a, p. 216]. Since that time, studies into the conceptualization of this the-

${ }^{1}$ Article received on 28 February 2020, accepted on 20 May 2020. 
ory and the development of a universal method to measure NIC have been continuing. However, until now no standard for the understanding, classification of as well as a set of diagnostic properties of NIC, have been established. The development of a clear conceptual framework has been hampered by NIC's characteristics [Michalczuk, Fiedorczuk, 2017b, p. 119-120]. As a consequence, the measurement of national intellectual capital is a very complex problem as well as an ongoing challenge for the world of science [Salonius, Lönnqvist, 2012, p. 333].

Despite their recognition, the new (intangible) determinants of economic wealth are still not being correctly adapted to its measurement. The current state of knowledge does not allow reporting systems or development models [Tubadji, 2014, p. 56] to include intellectual capital. This is a serious scientific problem since intellectual capital has been recognized as the main wealth generator of economies [Tsouli, Elabbadi, 2017, p. 27]. Additionally, it plays an important role in the process of current and future growth and development of states [Seleim, Bontis, 2013, p. 131]. At the same time, it has also become their primary source of competiveness [Labra, Sánchez, 2013, p. 15] and facilitates other economic benefits. The intellectual capital of a country is one of its most important sources of economic prosperity and has a significant impact on the nation's economic results [Bontis, 2004, p. 15].

The importance of knowledge regarding the level of intellectual capital of states has been emphasized by numerous authors. In the opinion of Edvinsson, Lin [2011, p. 253], it allows the identification of the economy's key development/competitive factors providing decision makers with its complete picture. According to Schuima et al. [2008, p. 292], monitoring of NIC allows control over progress in the realization process of knowledge development, government programs and policies being carried out, as well as provides a basis for behavioral assessment of people.

Despite a wide array of benefits, macroeconomic expression of intellectual capital is still a niche scientific area. According to Pedru et al. [2018, p. 418] this subject matter concerns only $0.4 \%$ of all scientific studies devoted to intellectual capital. A small number of works dealing with macroeconomic perspective supports the opinion expressed by Inkinen [2015, p. 519] who believes that NIC is a "reputable area of scientific research".

\section{Literature Review}

The national intellectual capital is an internally diverse category, one that is abstract and invisible, and thus is defined differently by different people. Difficulties in defining phenomena which possess a complex structure are especially common with respect to macroeconomic research [Wosiek, 2012, p. 47]. Over the years, a number of definitions have been developed, however, it has not yet been possible to identify one that could be considered to be the most commonly used. Intellectual capital reflects a set of intangible assets possessed by people, companies, communities, institutions in varying configurations, intensity and spatial diversity, difficult to diagnose but having a significant impact on the developmental capabilities of individual 
countries [Bombiak, 2015, p. 55]. Other, varying, descriptions of NIC have been listed in table 1.

TABLE 1

Review of approaches toward defining national intellectual capital

\begin{tabular}{|l|l|}
\hline \multicolumn{1}{|c|}{ Authors } & \multicolumn{1}{c|}{ Definition of NIC } \\
\hline $\begin{array}{l}\text { Andriessen, } \\
\text { Stam }\end{array}$ & $\begin{array}{l}\text { All intangible available resources that give a relative advantage and } \\
\text { which in combination are able to produce future benefits. }\end{array}$ \\
\hline Węziak & $\begin{array}{l}\text { The hidden values of individuals, enterprises, institutions, communi- } \\
\text { ties and regions that are the current and potential sources for wealth } \\
\text { creation. These hidden values are the roots for nourishment and the } \\
\text { cultivation of future wellbeing. IC cannot be observed directly. }\end{array}$ \\
\hline $\begin{array}{l}\text { Salonius, } \\
\text { Lönnqvist }\end{array}$ & $\begin{array}{l}\text { A bundle of assets which help a nation to purpose its goals related to } \\
\text { economic, social and environmental development. }\end{array}$ \\
\hline
\end{tabular}

Source: author's own work based on: [Andriessen, Stam, 2009, p. 490; Salonius, Lönnqvist 2012, p. 333; Węziak, 2007, p. 4].

Various authors define NIC differently and, as a consequence, there is no consensus in relation to its taxonomy [Michalczuk, Fiedorczuk, 2018b, p. 92]. This is conditioned by varying levels of aggregation, the degree of standard adaptation or the approach toward model evolution in time. The construction of NIC is most often a hierarchal structure.

This is reflected in the diversity of NIC diagnostic characteristics sets. Some researchers [Salonius, Lönnqvist, 2012, p. 333] claim that the development of a correct set of NIC diagnostic has the greatest impact on the results of NIC measurement. With their help, the more precise understanding of scope and components making up NIC is possible. Selected sets of diagnostic factors have been presented in table 2 .

Sets of NIC diagnostic attributes are characterized by being diverse on many levels and are determined through the specific character of the subject being addressed, the methods used and the goal of conducted research. The differences concern the type of variables, the manner in which they are presented and, in the opinion of Węziak-Białowolska [2010, p. 33], attribute to the sets' degree of complexity.

NIC quantification methods can be divided into two groups [Michalczuk, Fiedorczuk, 2018a, p. 285], specifically:

- methodology based on the analysis and assessment of segment indicators characterizing individual components of intellectual capital (qualitative measurement);

- methodology based on combining segment variables into one synthetic factor (index) of intellectual capital (quantitative measurement). 
TABLE 2

The review of diagnostic features sets of the national intellectual capital components

\begin{tabular}{|c|c|c|c|}
\hline \multicolumn{4}{|c|}{ Edvinsson, Lin } \\
\hline Human capital & Market capital & Process capital & Renewal capital \\
\hline $\begin{array}{l}\text { Skilled labor } \\
\text { Employee training } \\
\text { Literacy rate } \\
\text { Higher education } \\
\text { enrolment } \\
\text { Pupil-teacher ratio } \\
\text { Internet } \\
\text { subscribers } \\
\text { Public } \\
\text { expenditure on } \\
\text { education }\end{array}$ & $\begin{array}{l}\text { Corporate tax } \\
\text { Cross-border } \\
\text { venture } \\
\text { Culture openness } \\
\text { Globalization } \\
\text { Transparency } \\
\text { Image of country } \\
\text { Exports of goods }\end{array}$ & $\begin{array}{l}\text { Business competition } \\
\text { environment } \\
\text { Government efficiency } \\
\text { Intellectual property } \\
\text { rights protection } \\
\text { Capital availability } \\
\text { Computers in use } \\
\text { per capita } \\
\text { Convenience of } \\
\text { establishing new firms } \\
\text { Mobile phone } \\
\text { subscribers }\end{array}$ & $\begin{array}{l}\text { Business R\&D } \\
\text { spending } \\
\text { Basic research } \\
\text { R\&D spending/ } \\
\text { GDP } \\
\text { R\&D researchers } \\
\text { Cooperation } \\
\text { between } \\
\text { universities } \\
\text { and enterprises } \\
\text { Scientific articles }\end{array}$ \\
\hline \multicolumn{4}{|c|}{ Käpylä, Kujansivu, Lönnqvist } \\
\hline Human capital & Social capital & Structural capital & Relation capital \\
\hline $\begin{array}{l}\text { Secondary school } \\
\text { enrolment } \\
\text { Higher education } \\
\text { achievement } \\
\text { Skilled labour } \\
\text { Flexibility and } \\
\text { adaptability }\end{array}$ & $\begin{array}{l}\text { Social responsibil- } \\
\text { ity } \\
\text { Entrepreneurship } \\
\text { Ethical practices } \\
\text { Social cohesion } \\
\text { Knowledge trans- } \\
\text { fer }\end{array}$ & $\begin{array}{l}\text { Internet users } \\
\text { Computers per capita } \\
\text { Scientific articles } \\
\text { Patent productivity } \\
\text { Value system } \\
\text { Transparency } \\
\text { Justice }\end{array}$ & $\begin{array}{l}\text { Exports of goods } \\
(\% \text { GDP }) \\
\text { Exports of } \\
\text { commercial services } \\
\text { Image abroad } \\
\text { Relocation threats } \\
\text { of R\&D facilities }\end{array}$ \\
\hline
\end{tabular}

Source: author's own work based on: [Edvinsson, Lin, 2011, p. 255; Käpylä et al., 2012, p. 350].

The problem of measuring intellectual capital on the national scale is surprisingly current. It has become significant in connection with the actualization of economic growth factors which has resulted in the need to expand research concerning the concept of intellectual capital, especially with respect to economies based on knowledge. However, quantification of NIC is associated with numerous limitations. The first of these concerns the definition of this ambiguous concept since the best description has not yet been agreed upon. Others appear along with attempts to determine constituent elements and in particularizing its components through diagnostic attributes. These activities constitute only the initial stages of NIC quantification. 


\section{Measurement procedure of intellectual capital of the European Union countries}

The NIC measurement process consists of four stages. First of them constitutes the theoretical assumptions of national intellectual capital model. For the needs of this study, it has been accepted that the national intellectual capital of a particular country is the potential value inherent in the intangible and tangible knowledge products of its economy which depends on the financial capital and impacts social, economic and ecological processes. This value determines the current level of prosperity and the ability to improve it in the future [Bontis, 2004, p. 15].

Thus understood concept of intellectual capital consists of four components. The structure of NIC is presented in chart 1.

\section{Taxonomy of national intellectual capital}

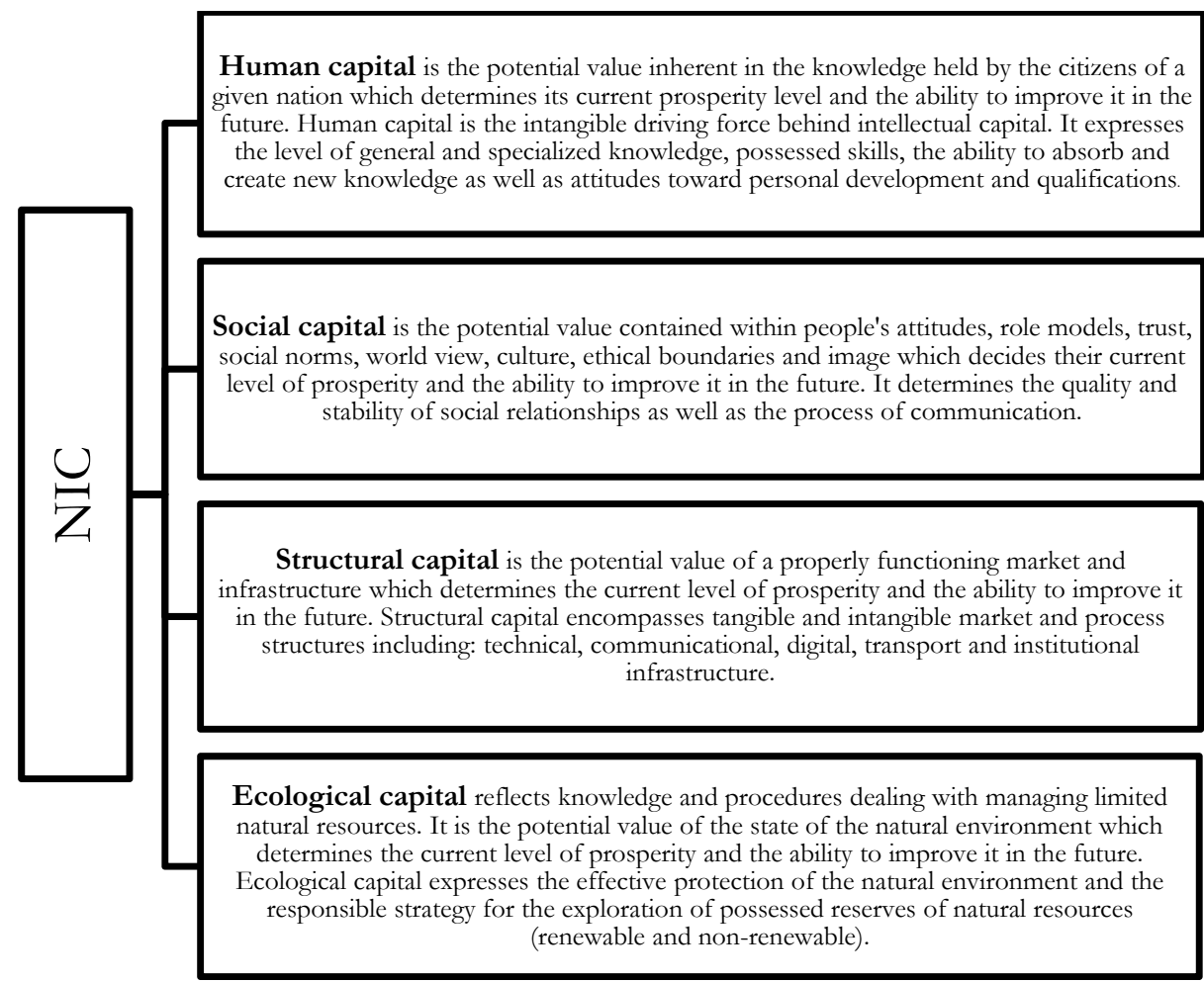

Source: author's own work.

The author includes the component of ecological capital in taxonomy of national intellectual capital. This innovative approach is meant to be a reaction to the current problem with access to a pollution-free environment, natural resources and healthy food. The significance of having to establish this category is confirmed in numerous 
scientific studies and the results of international organizations' reports. Assigning equal importance to the "natural" capital with respect to other forms of capital is essential for the correct management at the national level [Helm, 2015]. In the reviewed approaches, this type of capital rarely appears as an individual component of NIC. Its closest counterpart (socio-environmental capital) has been defined as a part of structural capital by only one team of researchers: Alfaro et al. [2011, p. 6711; 2014, pp. 263-264] and López et al. [2011, p. 264].

Intellectual capital possesses numerous characteristics which make its measurement difficult. It is a category that is immeasurable, intangible, non-uniform, renewable, unlimited, internally complex and prospective in character. National intellectual capital is a non-autonomous category. "The main characteristics of capital are movement, activity, circulation and non-existence" [Matysiak, 2008, p. 86]. Since capital is a non-independent entity, existing only as a part of a particular whole, NIC is always a part of a specified system which contains powers that can impact its state positively or negatively. For that reason, NIC should not be gauged separately from the environment within which it functions or processes connected to it. It is determined by the necessity of treating NIC as a part of a system in which it functions.

The second stage of the measurement process concerns the measurement method. To measure the intellectual capital of a selected group of countries the author of the present study uses the method of classic linear ordering of multi-attribute objects or the so called TOPSIS (Technique for Order Preference by Similarity to an Ideal Solution) method, which was created by Hwang and Yoon in 1981. The measurement of an uncountable category was conducted by [Perło, Roszkowska, 2017, pp. 72-73; Michalczuk et al., 2019].

The TOPSIS method consists of 7 stages [Roszkowska, Wachowicz, 2013, pp. 17-19]:

- Selection of diagnostic characteristics based on content-related and statistical assumptions. Roszkowska, Wachowicz [2013, pp. 13-14] declare that the coefficient of variability cannot be lower than $10 \%$.

- Division of diagnostic characteristics into stimulants, destimulants and nominants and assigning importance. Within the study it has been assumed that every component of NIC is equally important, therefore, all diagnostic characteristics have been assigned equal importance.

- Normalization of diagnostic characteristics' value. The study used the procedure of zeroed unitarisation through the utilization of the following equations:

for stimulants:

$$
z_{i k}=\frac{x_{i k}-\min _{i}\left\{x_{i k}\right\}}{\max _{i}\left\{x_{i k}\right\}-\min _{i}\left\{x_{i k}\right\}}
$$

for destimulants:

$$
z_{i k}=\frac{\max _{i}\left\{x_{i k}\right\}-x_{i k}}{\max _{i}\left\{x_{i k}\right\}-\min _{i}\left\{x_{i k}\right\}}
$$


for nominants:

$$
z_{i k}=\left\{\begin{array}{cc}
\frac{x_{i k}-\min _{i}\left\{x_{i k}\right\}}{c_{0 k}-\min _{i}\left\{x_{i k}\right\}} & \text { dla } x_{i k}<c_{0 k} \\
1 & \text { dla } x_{i k}=c_{0 k} \\
\frac{x_{i k}-\max _{i}\left\{x_{i k}\right\}}{c_{0 k}-\min _{i}\left\{x_{i k}\right\}} & \text { dla } x_{i k}>c_{0 k}
\end{array}\right.
$$

where: $i$ is the number of the object $(i=1,2, \ldots, n), k$ - the number of the diagnostic characteristic and $\mathrm{c}_{0 \mathrm{k}}$ is the nominal value of the $\mathrm{k}^{\text {th }}$ diagnostic characteristic.

- Calculation for every object of the Euclidean distance from the pattern and the non-pattern, using the following equations:

distance from pattern:

$$
d_{i}^{+}=\sqrt{\sum_{k=1}^{m}\left(z_{i k}-z_{k}^{+}\right)^{2}}
$$

distance from non-pattern:

$$
d_{i}^{-}=\sqrt{\sum_{k=1}^{m}\left(z_{i k}-z_{k}^{-}\right)^{2}}
$$

where: $i=1,2, \ldots, n$.

- Determination of synthetic measure values for each object in accordance with the formula [Hwang Yoon 1981, p. 132]:

$$
q_{i}=\frac{d_{i}^{-}}{d_{i}^{-}+d_{i}^{+}}
$$

where: $i=1,2, \ldots, n$.

The measure assumes a value from $<0,1>$ where the value 1 is reached for the standard and the 0 value - for non-standard.

- Ordering of the studied objects and their division into typological groups. Boundaries of divisions are delineated according to the following formulas [Nowak 1990, pp. 92-93]:

- $\quad$ group 1 (very high phenomenon level): $q_{i} \geq \bar{q}+s_{q}$,

- $\quad$ group 2 (high phenomenon level): $\bar{q} \leq q_{i}<\bar{q}+s_{q}$,

- $\quad$ group 3 (average and low phenomenon level): $\bar{q}-s_{q} \leq q_{i}<\bar{q}$,

- group 4 (very low phenomenon level): $g_{i}<\bar{q}-s_{g}$. where: mean average $-\bar{q}$, standard deviation $-S_{q}$ synthetic measure $-q_{i}$.

- Linear ordering of decision variants due to the value of their measure assessment.

The TOPSIS method provides a possibility for the quantitative complex description of a directly immeasurable socio-economic phenomenon. The assessment of its level is based on the value of one aggregated quantity (synthetic measure) which is quantified on the basis of a data set. The TOPSIS method determines the 
distance of the objects being reviewed from the ideal and the non-ideal solution. The object which is the closest to the ideal solution and, at the same time, is the furthest from the non-ideal solution, is considered to be the best. The value of the synthetic measure falls within the range of $<0-1>$ [Zalewski, 2012, p. 139].

The third stage of the measurement process is the elaboration of the diagnostic characteristics of intellectual capital of the EU countries, their verification and analysis. The development of an initial set of diagnostic characteristics is the first stage of the TOPSIS method. Regardless of the method used, the process of selecting variables is considered to hold a key role in the process of measuring NIC. This has been confirmed by Mačerinskienè and Aleknavičiūte [2017, p. 578].

Diagnostic characteristics selected for this study reflect the theoretical assumptions connected with the accepted concept of intellectual capital and its components. All of them are measurable. In accordance with the conceptual assumptions, some variables express visible artifacts of knowledge, such as, for example: the share of expenditures within GDP. The year 2015 is the study period. The selection of the study period was dictated by the availability of the most current data.

On the basis of a literature study, a preliminary set of diagnostic characteristics $\left(\mathrm{DS}_{0}\right)$, consisting of 57 attributes has been established. 18 of them concerned human capital (HC, 12 - social capital (SC), 13 - structural capital (SRC) and 14 - ecological capital (EC). All characteristics contained within the DS0 set are characterized by a high substantial value and measurability. In order to ensure comparability between the countries being considered in the study the characteristics have been presented as intensity factors. Missing data was filled in using data from the closest available period. Consequently, seven characteristics were described by data from 2016, data for two attributes concerned the year 2014 and data from 2013 reflected the state of three characteristics. These will create a data matrix $(\mathrm{m} \times \mathrm{n})$ of values reached by objects within each characteristic. In accordance with the assumptions of this method, the type of the characteristic is defined (stimulant/destimulant).

Despite the fact that the article's author believes that diagnostic characteristics impact NIC with varying intensity, within the study their equality was assumed. This simplification is the result of the author not possessing enough specialized knowledge in the fields of ecology, environment, sociology and technology which is crucial in the process of assigning importance to each characteristic. This point has also been made by Hervas-Oliver et al. [2011, p. 115] who claim that assigning importance to diagnostic characteristics on the basis of one's own judgment causes interference with the final result of the study.

The DS0 set was subjected to statistical verification. Elimination of excessively correlated characteristics was conducted on the basis of the inverted correlation matrix method. According to Malina, Zeliaś [1997, p. 11-27] the algorithm of this method progressed through the following steps:

- designation of a correlation matrix;

- designation of a matrix inverse to the correlation matrix; 
- determination of a critical value for diagonal elements of inverted matrix at 10. On the basis of this condition 2 characteristics, KL_19 and KE_2, were removed from the set;

- identification of diagonal elements of the inverted matrix with respect to the module smaller than the assumed critical value;

- reduction of the characteristics through the elimination of attributes which do not fulfill the condition formulated during the previous step.

On account of the large number of characteristics contained within the DS0 set, the algorithm was run separately for each of the identified components of NIC which resulted in a new set of potential diagnostic characteristics - the $\mathrm{DS}_{1}$ set which consisted of 20 attributes. The values of the characteristics within the $\mathrm{DS}_{1}$ set are characterized by great variance. Unlike previous activities, at this stage the elimination of attributes was based on the results of one inverse matrix covering the data of 4 components of NIC. As a result of these actions, 3 characteristics: HC_9 "Total R\&D expenditure in GDP [\%]", SRC_7 - "Fatal traffic accidents per 100,000 inhabitants" and SRC_10 - "Number of airports serving over 15,000 passenger units annually/capita" were discarded creating a final set of diagnostic attributes the DS2 set. As a consequence, thirteen stimulants and four destimulants were subjected to proper examination. 11 features reflect the situation in 2015, 6 are described by 2016 data (KL_8, KL_14, KS_1, KSTR_12, KSTR_13, KE_10).

Attributes qualified for the construction of the synthetic NIC indicator were subjected to statistical analysis. Basic statistical measures of DS2 set have all been presented in table 3 .

TABLE 3

Basic descriptive statistic of the set of diagnostic characteristics (DS2)

\begin{tabular}{|c|c|c|c|c|c|c|}
\hline Sym. & Diagnostic feature & & & & Max. & Min. \\
\hline HC_2 & $\begin{array}{l}\text { Population attending the } \\
\text { training after completing } \\
\text { basic education [\%] }\end{array}$ & 14.99 & 7.15 & 47.68 & $\begin{array}{l}34.70 \\
\text { Denmark }\end{array}$ & $\begin{array}{l}5.80 \\
\text { Romania }\end{array}$ \\
\hline $\mathrm{HC}_{-} 7$ & $\begin{array}{l}\text { Population with mobile In- } \\
\text { ternet access [\%] }\end{array}$ & 27.46 & 8.56 & 31.16 & $\begin{array}{l}45.00 \\
\text { Finland }\end{array}$ & $\begin{array}{l}13.00 \\
\text { Italy }\end{array}$ \\
\hline HC_8 & $\begin{array}{l}\text { Population using electronic } \\
\text { banking (buying shares, } \\
\text { bonds, taking loans) }\end{array}$ & 13.64 & 11.72 & 85.93 & $\begin{array}{l}38.00 \\
\text { Italy }\end{array}$ & $\begin{array}{l}2.00 \\
\text { Slovakia }\end{array}$ \\
\hline HC_13 & $\begin{array}{l}\text { New doctoral graduates } \\
\text { per one thousand of } \\
\text { population, aged } 25-34\end{array}$ & 1.80 & 0.86 & 48.03 & $\begin{array}{l}3.55 \\
\text { Slovenia }\end{array}$ & $\begin{array}{l}0.63 \\
\text { Poland }\end{array}$ \\
\hline HC_14 & $\begin{array}{l}\text { Research and development } \\
\text { personnel of private sector } \\
{[\%]}\end{array}$ & 42.36 & 15.53 & 36.66 & $\begin{array}{l}66.97 \\
\text { Sweden }\end{array}$ & $\begin{array}{l}18.46 \\
\text { Latvia }\end{array}$ \\
\hline HC_15 & $\begin{array}{l}\text { Patent applications to the } \\
\text { EPO per employees in } \\
\text { B\&R }\end{array}$ & 1.22 & 1.04 & 84.98 & $\begin{array}{l}3.50 \\
\text { Sweden }\end{array}$ & $\begin{array}{l}0.14 \\
\text { Bulgaria }\end{array}$ \\
\hline
\end{tabular}




\begin{tabular}{|c|c|c|c|c|c|c|}
\hline Sym. & Diagnostic feature & & & & Max. & Min. \\
\hline SC_1 & $\begin{array}{l}\text { The number of suicides } \\
\text { per } 100,000 \text { inhabitants }\end{array}$ & 8.71 & 4.37 & 50.18 & $\begin{array}{l}23.60 \\
\text { Greece }\end{array}$ & $\begin{array}{l}4.00 \\
\text { Czech Rep. }\end{array}$ \\
\hline SC_2 & Adolescent fertility rate & 17.43 & 8.12 & 46.59 & $\begin{array}{l}47.50 \\
\text { Lithuania }\end{array}$ & $\begin{array}{l}6.10 \\
\text { Greece }\end{array}$ \\
\hline SC_5 & $\begin{array}{l}\text { Population attending } \\
\text { formal and non-formal } \\
\text { education and training [\%] }\end{array}$ & 11.68 & 8.85 & 75.81 & $\begin{array}{l}39.40 \\
\text { Bulgaria }\end{array}$ & $\begin{array}{l}3.20 \\
\text { Netherlands }\end{array}$ \\
\hline SC_6 & Active population [\%] & 22.43 & 15.14 & 67.50 & $\begin{array}{l}58.00 \\
\text { Netherlands }\end{array}$ & $\begin{array}{l}0.90 \\
\text { Malta }\end{array}$ \\
\hline SRC_1 & Unemployment rate & 9.34 & 5.75 & 61.52 & $\begin{array}{l}24.60 \\
\text { France }\end{array}$ & $\begin{array}{l}2.10 \\
\text { Cyprus }\end{array}$ \\
\hline SRC_7 & $\begin{array}{l}\text { High technology export } \\
\text { [USD per capita] }\end{array}$ & 1285.75 & 1443.17 & 112.24 & $\begin{array}{l}7147.00 \\
\text { Ireland }\end{array}$ & $\begin{array}{l}35.90 \\
\text { Cyprus }\end{array}$ \\
\hline SRC_13 & $\begin{array}{l}\text { Raw material productivity } \\
{[\text { EURO/kg] }}\end{array}$ & 1.76 & 1.11 & 63.04 & $\begin{array}{l}4.18 \\
\text { Netherlands }\end{array}$ & $\begin{array}{l}0.29 \\
\text { Bulgaria }\end{array}$ \\
\hline EC_1 & Annual average PM 2.5 & 13.79 & 4.90 & 35.58 & $\begin{array}{l}24.10 \\
\text { Bulgaria } \\
\end{array}$ & $\begin{array}{l}5.30 \\
\text { Finland }\end{array}$ \\
\hline EC_4 & $\begin{array}{l}\text { Renewable energy in total } \\
\text { consumption }\end{array}$ & 19.80 & 11.70 & 59.08 & $\begin{array}{l}53.93 \\
\text { Sweden }\end{array}$ & $\begin{array}{l}4.99 \\
\text { Luxem- } \\
\text { bourg }\end{array}$ \\
\hline EC_10 & $\begin{array}{l}\text { Organic area in total agri- } \\
\text { cultural area }[\%]\end{array}$ & 7.76 & 5.34 & 68.81 & $\begin{array}{l}21.25 \\
\text { Austria }\end{array}$ & $\begin{array}{l}0.21 \\
\text { Malta }\end{array}$ \\
\hline EC_12 & Recycling rate & 35.99 & 14.56 & 40.45 & $\begin{array}{l}66.00 \\
\text { Germany }\end{array}$ & $\begin{array}{l}7.00 \\
\text { Malta }\end{array}$ \\
\hline
\end{tabular}

grey color - destimulant

Source: author's own work based on: Eurostat's, European Innovation Scoreboard's, World Bank's, WHO's, EEA's data.

The diagnostic characteristics have been normalized. For this purpose, zeroed unitarisation was used. Normalizing variables allows variables to be compared. As a result, scorecards of European countries were prepared in terms of 17 diagnostic features, which are presented in table 4.

Obtaining the intellectual capital index of the EU countries (NICI) constitutes the fourth stage of measurement process. The NICI calculation process was carried out in accordance with formula 6 .

Chart 2 presents the value of the hidden variable synthetic measure of the intellectual capital of the EU countries in 2015. The results are shown in descending order. 
TABLE 4

European countries scorecard on 17 diagnostic characteristics

\begin{tabular}{|c|c|c|c|c|c|c|c|c|c|c|c|c|c|c|c|c|c|}
\hline EU-28 & $\underbrace{}_{1}$ & I & $\theta_{1}^{\infty}$ & $\stackrel{3}{\theta}$ & $\begin{array}{l}\nabla_{1} \\
\forall\end{array}$ & $\frac{1}{2}$ & $\frac{\sigma}{1}$ & $\vec{*}$ & $\begin{array}{l}N_{1} \\
\tilde{N}\end{array}$ & $\begin{array}{l}n \\
n \\
0\end{array}$ & $\begin{array}{l}0 \\
0 \\
\forall\end{array}$ & \begin{tabular}{l} 
I \\
-1 \\
\multirow{2}{*}{}
\end{tabular} & $\begin{array}{l}2 \\
-1 \\
\tilde{n}\end{array}$ & $\overrightarrow{\mid r}$ & $\begin{array}{l}\sigma_{1} \\
\text { I }\end{array}$ & 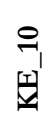 & 긴 \\
\hline AUS & 8 & 16 & 18 & 13 & 2 & 3 & 8 & 16 & 10 & 9 & 8 & 4 & 12 & 17 & 4 & 1 & 2 \\
\hline BEL & 15 & 6 & 14 & 11 & 11 & 8 & 15 & 23 & 9 & 13 & 22 & 2 & 7 & 16 & 25 & 17 & 4 \\
\hline BUL & 27 & 22 & 27 & 17 & 15 & 28 & 14 & 8 & 28 & 25 & 25 & 25 & 28 & 28 & 12 & 23 & 20 \\
\hline CRO & 25 & 24 & 23 & 19 & 25 & 27 & 26 & 20 & 17 & 16 & 20 & 22 & 18 & 20 & 6 & 16 & 23 \\
\hline CYP & 18 & 20 & 24 & 27 & 23 & 15 & 25 & 2 & 5 & 27 & 28 & 28 & 15 & 18 & 22 & 19 & 24 \\
\hline CZE & 13 & 11 & 11 & 15 & 12 & 21 & 1 & 15 & 19 & 17 & 24 & 6 & 19 & 19 & 17 & 4 & 15 \\
\hline DEN & 1 & 5 & 3 & 2 & 6 & 6 & 10 & 9 & 2 & 6 & 16 & 7 & 10 & 6 & 5 & 11 & 8 \\
\hline EST & 10 & 15 & 5 & 21 & 21 & 16 & 12 & 26 & 21 & 10 & 11 & 16 & 25 & 4 & 7 & 3 & 22 \\
\hline FIN & 3 & 1 & 6 & 4 & 9 & 4 & 19 & 21 & 8 & 2 & 4 & 17 & 21 & 1 & 2 & 7 & 12 \\
\hline FRA & 6 & 9 & 15 & 14 & 4 & 7 & 22 & 18 & 16 & 12 & 1 & 8 & 5 & 10 & 16 & 18 & 13 \\
\hline GER & 14 & 12 & 16 & 5 & 7 & 2 & 2 & 10 & 12 & 21 & 7 & 11 & 9 & 12 & 18 & 13 & 1 \\
\hline GB & 7 & 3 & 4 & 3 & 16 & 10 & 3 & 6 & 23 & 20 & 6 & 9 & 4 & 5 & 24 & 25 & 11 \\
\hline GRE & 26 & 18 & 9 & 20 & 27 & 26 & 28 & 1 & 13 & 19 & 13 & 5 & 16 & 25 & 15 & 15 & 25 \\
\hline HUN & 17 & 14 & 20 & 22 & 5 & 17 & 4 & 22 & 25 & 24 & 23 & 21 & 22 & 23 & 19 & 21 & 18 \\
\hline IRE & 21 & 19 & 10 & 7 & 13 & 12 & 18 & 17 & 15 & 11 & 12 & 1 & 8 & 3 & 23 & 26 & 14 \\
\hline ITA & 19 & 28 & 1 & 16 & 14 & 9 & 24 & 3 & 6 & 22 & 19 & 14 & 3 & 22 & 13 & 5 & 9 \\
\hline LAT & 22 & 26 & 12 & 25 & 28 & 20 & 20 & 27 & 24 & 8 & 21 & 27 & 26 & 8 & 3 & 6 & 21 \\
\hline LIT & 16 & 25 & 17 & 23 & 24 & 25 & 16 & 28 & 22 & 18 & 18 & 18 & 23 & 9 & 9 & 12 & 17 \\
\hline LUX & 5 & 4 & 7 & 18 & 17 & 11 & 11 & 13 & 7 & 7 & 5 & 19 & 2 & 11 & 28 & 22 & 6 \\
\hline MAL & 20 & 8 & 8 & 26 & 8 & 19 & 5 & 5 & 18 & 28 & 10 & 10 & 13 & 15 & 27 & 28 & 28 \\
\hline NET & 4 & 7 & 21 & 9 & 3 & 5 & 7 & 7 & 1 & 1 & 3 & 12 & 1 & 13 & 26 & 24 & 5 \\
\hline POL & 23 & 23 & 2 & 28 & 19 & 18 & 9 & 25 & 20 & 3 & 15 & 3 & 24 & 27 & 21 & 20 & 10 \\
\hline POR & 12 & 13 & 22 & 12 & 20 & 23 & 23 & 12 & 14 & 14 & 9 & 20 & 20 & 7 & 8 & 14 & 19 \\
\hline ROM & 28 & 27 & 19 & 24 & 22 & 22 & 6 & 11 & 27 & 26 & 26 & 23 & 27 & 21 & 10 & 27 & 27 \\
\hline SLOVA & 24 & 10 & 28 & 10 & 26 & 24 & 21 & 19 & 26 & 15 & 17 & 24 & 17 & 24 & 20 & 8 & 26 \\
\hline SLOVE & 9 & 17 & 13 & 1 & 10 & 13 & 17 & 24 & 4 & 5 & 27 & 13 & 14 & 26 & 11 & 9 & 3 \\
\hline SPA & 11 & 21 & 25 & 8 & 18 & 14 & 27 & 4 & 11 & 23 & 14 & 26 & 6 & 14 & 14 & 10 & 16 \\
\hline SWE & 2 & 2 & 26 & 6 & 1 & 1 & 13 & 14 & 3 & 4 & 2 & 15 & 11 & 2 & 1 & 2 & 7 \\
\hline
\end{tabular}

Source: author's own work. 
CHART 2

Value of the national intellectual capital index (NICI) of the European Union countries in 2015

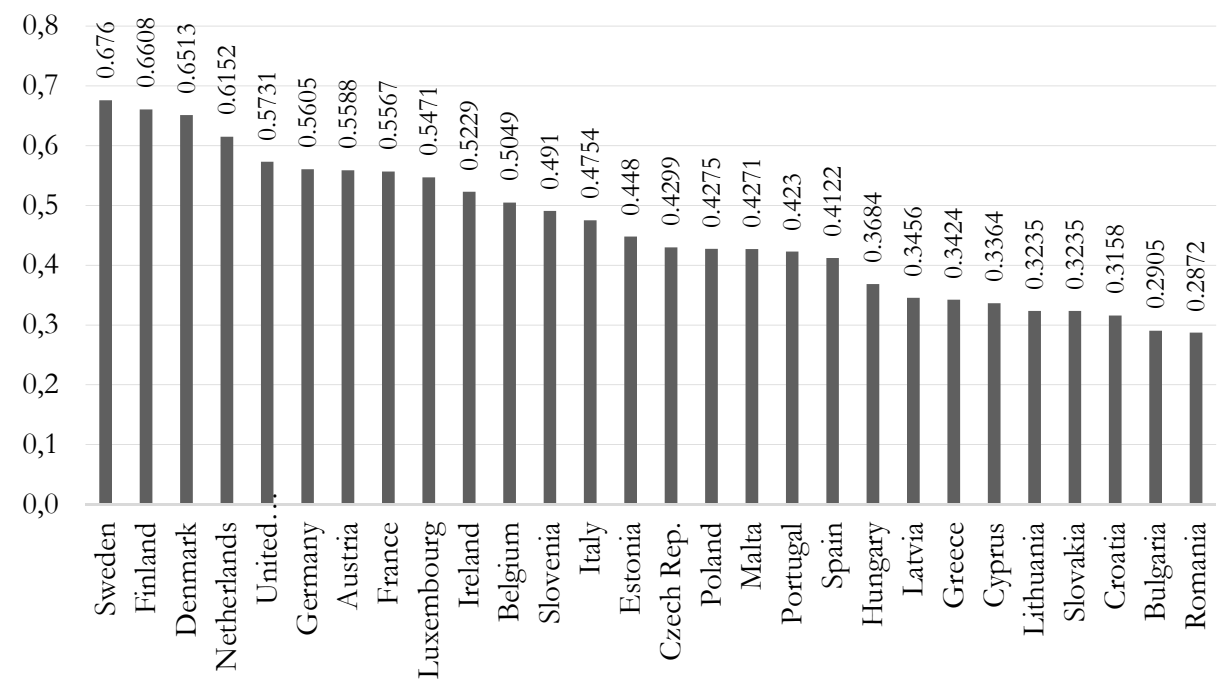

Source: author's own work.

CHART 3

Spatial variance of European countries in 2015 on the basis of the NICI ranking

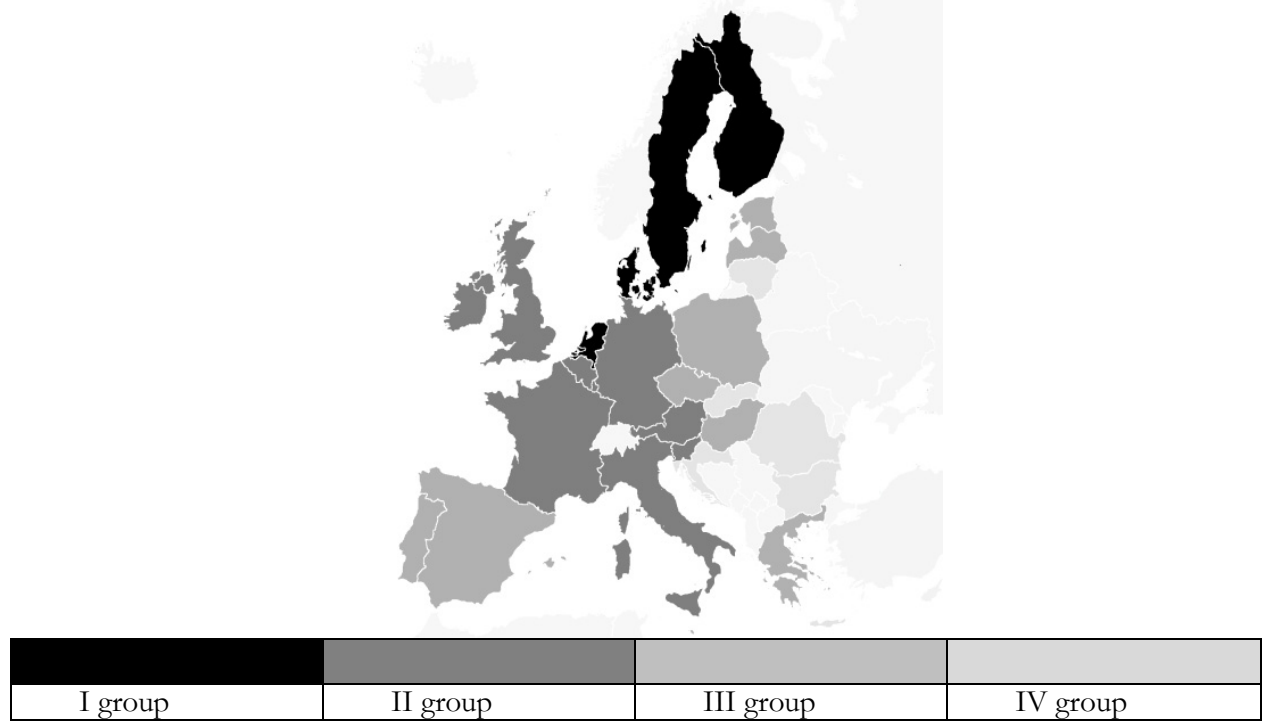

Source: author's own work. 
The level of intellectual capital of the EU countries shows a variance at a level of $25.24 \%$. In that ranking Sweden takes the first place with a result of 0.676. The smallest NICI value in the ranking (0.2872) reflects the potential for intellectual capital of Romania. The value of population standard deviation is 0.116 . The average level of intellectual capital in states considered in the study is 0.461 .

A classification of the EU states was performed establishing four typological groups (chart 3).

The northern regions of the European Union are occupied by the states from group 1, those with a very high potential for intellectual capital, mainly Scandinavian countries. Nations which display a high potential for intellectual capital - group 2, are located in Central Europe. Eastern Europe and the West (Spain and Portugal) are occupied by countries having a moderate and low potential for intellectual capital (group 3). States from the typological group 4 are located in Eastern Europe.

\section{Conclusions}

The main aim of the article was the proposal of a new, theoretical and methodological approach to measuring national intellectual capital (NIC) and its application in the assessment of the potential of the EU nations (in 2015) in this respect. The realization of this goal consisted of multiple phases. On the basis of the completed analysis the author developed her own definition of NIC and specified its components including a new element, that of ecological (natural) capital. Subsequent steps were determined through the use of the TOPSIS method which was utilized to select and verify variables chosen for the study with the quantification of the synthetic indicator completed on their basis. Measurable results of the study include: a ranking of 28 countries and their division into so-called typological groups. As a result, it can be ascertained that the new method allows to measure an unobservable category of NIC. The highest index value applies to Sweden. Romania takes the last -28 th place and belongs to the fourth typological group with a very low potential of intellectual capital. The results of the research complete the information gap on intangible factors of wealth creation in economies and provide knowledge on the possibilities of development of the country. They can be used in political activities, improving the process of shaping the strategic objectives, associated mainly with development.

Other than the unclear conceptual framework of NIC, limited access to appropriate data is the greatest obstacle in its measuring. Despite this, the results obtained can be regarded as reliable and satisfactory. The original method developed by the author to measure NIC allows to consider a wide range of factors. In particular, the approach to NIC taxonomy (isolation of ecological capital) allows the contemplation of important and previously overlooked world problems.

The concept of the "green intellectual capital" or GIC addressed at the microeconomic level by Delgado-Verde et al. [2014], Yadiati et al. [2019] and Yusoff et al. [2019] as well as that of "sustainable intellectual capital" described by Cavicchi and Vagnoni [2017] were an inspiration in specifying the notion of ecological capital 
within the structure of NIC. The natural environment and its state seem to be one of the most important challenges currently faced by governments and societies.

The contemplated problem requires further empirical and theoretical exploration. The obtained results can be utilized in future research concerning the following issues:

1. The use of the proposed approach in measuring national intellectual capital for different periods of time.

2. The use of the proposed approach in measuring national intellectual capital for different objects.

3. Characterization of needed information that is currently unavailable and which could, in the future, improve study results.

4. The analysis of causes of the low level of intellectual capital in specified countries as well as success factors in the group of nations displaying the highest value of the NIC index.

\section{References}

Alfaro J.-L., López V.-R., Nevado D., 2011, An Alternative to measure national intellectual capital adopted from business level, "African Journal of Business Management", vol. 5(16), pp. 6707-6716, DOI: 10.5897/AJBM10.1228.

Alfaro J.-L., López V.-R., Nevado D., 2014, Economic Growth and intangible capitals: Europe versus Asia, "Panoeconomicus", vol. 61(3), pp. 261-274, DOI: 10.2298/ PAN1403261N.

Andriessen D., Stam C., 2009, Intellectual Capital of the European Union 2008: Measuring the Lisbon Strategy for Growth and Jobs, "Electronic Journal of Knowledge Management", vol. 7(4), pp. 489-500,

Bombiak E., 2015, Diagnoza kapitatu intelektualnego w ujeciu makroekonomicznym - przeglad koncepcji teoretycznych i podejśc badawczych, „Marketing i Rynek”, vol. 10, pp. 54-63.

Bontis N., 2004, National Intellectual Capital Index. A United Nations Initiative for the Arab region, 'Journal of Intellectual Capital", vol. 5(1), pp. 13-39, DOI: 10.1108/ 14691930410512905.

Cavicchi C., Vagnoni E., 2018, Does intellectual capital promote the shift of healthcare organizations towards sustainable development? Evidence from Italy, "Journal of Cleaner Production”, vol. 153, pp. 257-286, DOI: 10.1016/j.jclepro.2017.03.175.

Delgado-Verde M., Amores-Salvado J., Martin-de Castro G., Navas-Lòpez J.E., 2014, Green intellectual capital and environmental product innovation: the mediating role of green social capital, "Knowledge Management Research \& Practice", vol. 12(3), pp. 261275, DOI: $10.1057 / \mathrm{kmrp} .2014 .8$.

Edvinsson L., Lin C., 2011, What national intellectual capital indices can tell about the global economic crisis of 2007-2009?, "Electronic Journal of Knowledge Management", vol. 8(2), pp. 253-266.

Hervas-Oliver J.L., Rojas R., Martins B.M., Carvelló-Royo R., 2011, The overlapping of national IC and innovation systems, "Journal of Intellectual Capital", vol. 12(1), pp. 111-131, DOI: 10.1108/14691931111097935. 
Helm D., 2015, Natural capital - V aluing the Planet, Yale University Press, New Heven and London.

Hwang C.L., Yoon K., 1981, Multiple attribute decision making-methods and applications, Springer-Verlag, Berlin, Heidelberg, New York.

Inkinen I., 2015, Review of empirical research on intellectual capital and firm performance, "Journal of Intellectual Capital", vol. 16(3), pp. 518-565, DOI: 10.1108/JIC-012015-0002.

Käpylä J., Kujansivu P., Lönnqvist A., 2012, National intellectual capital performance: a strategic approach, "Journal of Intellectual Capital", vol. 13(3), pp. 343-362, DOI: 10.1108/14691931211248909.

Labra R., Sánchez M.P., 2013, National intellectualcapital assessment models a literature review, "Journal of Intellectual Capital", vol. 5(1), pp. 582-607, DOI: 10.1108/ JIC-112012-0100.

López V.R., Nevado D., Alfaro J.L., Badea L., Grigorescu A., Voinea L., 2011, Measurement of national non-visible wealth through intellectual capital, "Romanian Journal of Economic Forecasting", vol. 14(3), pp. 200-212.

Mačerinskienè I., Aleknavičiūtè R., 2017, National intellectual capital influence on economic growth in the European Union countries, "Equilibrium. Quarterly Journal of Economics and Economic Policy", vol. 12(4), pp. 573-592.

Malina A., Zeliaś A., 1997, Taksonomiczna analiza pržestrzennego zróżnicowania jakości ìycia ludności w Polsce w 1994 r., „Przegląd Statystyczny”, z. 1, pp. 11-27.

Matysiak A., 2008, Kapitat jako proces, „Zeszyty Naukowe. Polskie Towarzystwo Ekonomiczne", nr 6, pp. 85-101.

Michalczuk G., Fiedorczuk J., 2017a, Analysis of conceptualization and taxonomy of division of national intellectual capital (NIC), "Entrepreneurship and Management", vol. 18(1), pp. 213-223.

Michalczuk G., Fiedorczuk J., 2017b, Macroeconomic perspective of intellectual capital - national intellectual capital (NIC), "Optimum. Economic Studies", vol. 5(89), pp. 117133, DOI: 10.15290/ose.2017.05.89.08.

Michalczuk G., Fiedorczuk J., 2018a, Pomiar kapitału intelektualnego kraju - uybrane problem, „Prace Naukowe Uniwersytetu Ekonomicznego we Wrocławiu”, vol. 509, pp. 282-291, DOI: $10.15611 /$ pn.2018.509.24.

Michalczuk G., Fiedorczuk J., 2018b, National intellectual capital taxonomy, "Economics and Business", vol. 32, pp. 89-101, DOI: 10.2478/eb-2018-0007.

Michalczuk G., Skrodzka I., Paszko J., 2019, National Intellectual Capital in European Union Countries in 2013-2017, "European Research Studies Journal”, vol. XXII(4), pp. 115-125, DOI: $10.35808 /$ ersj/1501.

Nowak E., 1990, Metody takesonomiczne w klasyfikacji obiektón społeczno-gospodarczych, PWE, Warszawa.

Paszko J., 2019, Koncepcja kapitatu intelektualnego w teorii ekonomii [w:] Rola kapitatu w roz̨oju organizacji, Z., Kuciński A. (red.), Wyd. Akademii im. Jakuba z Paradyża w Gorzowie Wielkopolskim, Gorzów Wielkopolski.

Pedru E., Leitão J., Alves H., 2018, Intellectual capital and performance, "Journal of Intellectual Capital”, vol. 19(2), pp. 407-452, DOI: 10.1108/JIC-11-2016-0118. 
Perło D., Roszkowska E., 2017, The Application of Soft Modelling and TOPSIS Method for The Analysis of Competitiveness of Companies in Urban Functional Areas in Poland, "Optimum. Economic Studies", vol. 5(89), pp. 67-84, DOI: 0.15290/ose.2017. 05.89.05.

Roszkowska E., Wachowicz T., 2013, Metoda TOPSIS i jej rozszerzenia - studium metodologiczne, „Prace Naukowe Uniwersytetu Ekonomicznego w Katowicach”, pp. 11-40.

Salonius H., Lönnqvist A., 2012, Exploring the policy relevance of national intellectual capital information, "Journal of Intellectual Capital", vol. 13(3), pp. 331-342, DOI: 10.1108 /14691931211248891.

Schiuma G., Lerro A., Carlluci D., 2008, The know are tree and the regional intellectual capital index. An Assessment within Italy, "Journal of Intellectual Capital", vol. 9(2), pp. 283-300, DOI: 10.1108/14691930810870346.

Seleim A., Bontis N., 2013, National intellectual capital and economic performance: Empirical evidence from developing countries, "Knowledge and Process Management", vol. 20(3), pp. 131-140, DOI: 10.1002/kpm.1412.

Ståhle P., Ståhle S., Lin C., 2015, Intangibles and national economic wealth - a new perspective on how they are linked, "Journal of Intellectual Capital", vol. 16(1), pp. 20-57, DOI: 10.1108/JIC-02-2014-0017.

Tubadji A., 2014, Was Weber right? The cultural capital root of socio-economic growth examined in five European countries, "International Journal of Manpower", vol. 35(1/2), pp. 56-88, DOI: 10.1108/IJM-08-2013-0194.

Tsouli D., Elabbadi B., 2017, Intellectual capital assessment models in clusters: A literature review, "Global Journal of Management and Business research: Economics and Commerce", vol. 17(5), pp. 26-31.

Węziak-Białowolska D., 2010, Model kapitału intelektualnego regionu. Koncepcja pomiaru i jej zastosowania, Wydawnictwo Szkoły Głównej Handlowej, Warszawa.

Węziak D., 2007, Measurement of national intellectual capital: application to EU countries, IRISS Working Papers.

Wosiek M., 2012, Kapitat intelektualny w rozwoju regionów Polski Wschodniej, Wydawnictwo Uniwersytetu Rzeszowskiego, Rzeszów.

Yadiati W., Nissa N., Paulus S., Suharman H., Meiryani M., 2019, The Role of Green Intellectual Capital and Organizational Reputation in Influencing Environmental Performance, "International Journal of Energy Economics and Policy", vol. 9(3), pp. 261-268, DOI: 10.32479/ijeep.7752.

Yusoff Y., Omar M.K., Delima M., Zaman K., 2019, Do all elements of green intellectual capital contribute toward business sustainability? Evidence from Malaysian context using the Partial Least Squares method, "Journal of Cleaner Production", vol. 234, pp. 626637, DOI: 10.1016/j.jclepro.2019.06.153.

Zalewski W., 2012, Zastosowanie metody TOPSIS do oceny kondyci finansowej spótek dystrybucyjnych energii elektrycznej, „Economics and Management”, nr 4(4), pp. 137-145. 